\title{
DESINFESTAÇÃO E ESTABELECIMENTO IN VITRO DE ZEYHERIA MONTANA MART
}

\author{
Lílian de Almeida Brito ${ }^{1}$ \\ Luiz Carlos Araújo² \\ Maria Luiza de Azevedo ${ }^{3}$ \\ Samuel Cunha Oliveira Giordani ${ }^{4}$ \\ Miranda Titon ${ }^{5}$
}

Resumo: Zeyheria Montana é uma espécie com comprovado potencial medicinal e de recuperação de áreas degradadas, porém apresenta problemas de multiplicação em escala. Uma alternativa é a utilização da cultura de tecidos in vitro, que tem como fase crítica a desinfestação dos explantes para obtenção de uma cultura asséptica. Este trabalho teve o objetivo de verificar o efeito do tempo de imersão em hipoclorito de sódio na desinfestação e emergêcia in vitro de sementes de Zeyheria montana. Utilizou-se o delineamento experimental inteiramente casualizado (DIC) composto por quatro tempos de imersão em hipoclorito de sódio 2,5\% de cloro ativo (0; 2,5; 5 e 10 minutos), com quatro repetições. Os dados foram submetidos a analise de variância, ao teste Tukey a 5\% de significância. Os resultados demonstraram que as sementes imersas em hipoclorito de sódio durante 10 minutos, apresentaram maior porcentagem de emergência e menores porcentagens de contaminação fúngica e/ou bacteriana. Conclui-se que a utilização de hipoclorito de sódio se mostrou satisfatório para desinfestação e emergência das sementes de bolsa de pastor.

Palavras-chave: Bolsa-de-pastor; Cerrado; Germinação; Desinfestação; Micropropagação.

\footnotetext{
1 Mestranda em Ciência Florestal/Universidade Federal dos Vales do Jequitinhonha e Mucuri, Brasil. E-mail: liliandab2@gmail.com.

2 Doutorando em Ciência Florestal/Universidade Federal dos Vales do Jequitinhonha e Mucuri, Brasil. E-mail: luizcarlos.engflorestal@gmail.com.

3 Mestranda em Ciência Florestal/Universidade Federal dos Vales do Jequitinhonha e Mucuri, Brasil. E-mail: luhh.azevedo@gmail.com.

${ }^{4}$ Doutorando em Produção Vegetal/Universidade Federal dos Vales do Jequitinhonha e Mucuri, Brasil. E-mail: samuelgiordani@gmail.com.

5 Professora do Departamento de Engenharia Florestal /Universidade Federal dos Vales do Jequitinhonha e Mucuri, Brasil. E-mail: mtiton@ufvjm.edu.br.
} 